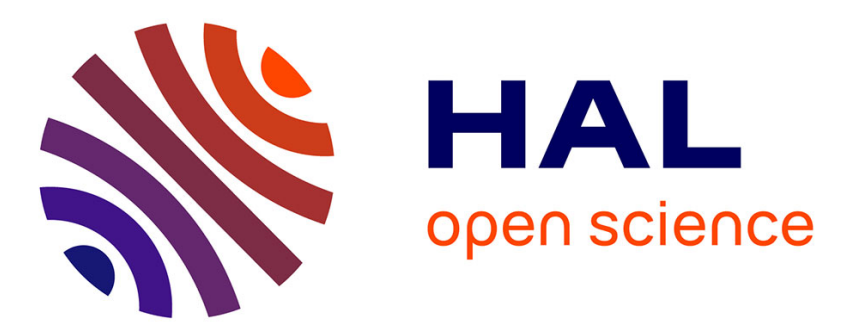

\title{
Gene flow estimation with microsatellites in a Malagasy seed orchard of Eucalyptus grandis
}

\author{
G. Chaix, S. A. Gerber, V. Razafimaharo, P. Vigneron, D. Verhaegen, S. \\ Hamon
}

\section{> To cite this version:}

G. Chaix, S. A. Gerber, V. Razafimaharo, P. Vigneron, D. Verhaegen, et al.. Gene flow estimation with microsatellites in a Malagasy seed orchard of Eucalyptus grandis. TAG Theoretical and Applied Genetics, 2003, 107, pp.705-712. cirad-00846100

\section{HAL Id: cirad-00846100 http://hal.cirad.fr/cirad-00846100}

Submitted on 18 Jul 2013

HAL is a multi-disciplinary open access archive for the deposit and dissemination of scientific research documents, whether they are published or not. The documents may come from teaching and research institutions in France or abroad, or from public or private research centers.
L'archive ouverte pluridisciplinaire HAL, est destinée au dépôt et à la diffusion de documents scientifiques de niveau recherche, publiés ou non, émanant des établissements d'enseignement et de recherche français ou étrangers, des laboratoires publics ou privés. 


\section{G. Chaix $\cdot$ S. Gerber $\cdot$ V. Razafimaharo $\cdot$ P. Vigneron • \\ D. Verhaegen $\cdot S$. Hamon}

\section{Gene flow estimation with microsatellites in a Malagasy seed orchard of Eucalyptus grandis}

Received: 16 August 2002 / Accepted: 17 March 2003 / Published online: 14 May 2003

(C) Springer-Verlag 2003

\begin{abstract}
Eucalyptus grandis has a mixed-mating reproductive system. Malagasy Eucalyptus seed orchards were established 15 years ago with two aims both based on panmixia: open-pollinated seed production and genetic improvement. The panmixia hypothesis has never been confirmed in the seed orchard. From a seedling seedorchard stand comprising 349 trees and using data obtained with six selected microsatellite markers, paternity analysis was performed for 724 offspring collected on 30 adult trees. Paternity assignment, based on exclusion procedures and likelihood-ratio method, was achieved with high accuracy; the exclusion probability value was 0.997 . The outcrossing rate was very high $(96.7 \%)$. More than $50 \%$ of potential male trees (199 out of 349) in the seed orchard contributed to pollination for 440 offspring of 30 progenies $(8.6 \%$ of the basic population). The pollination rate from outside the seed orchard was high (39.2\%), but might be due to the small size of this seed orchard. This study showed that "panmixia-like pollination" can be assumed.
\end{abstract}

Keywords Eucalyptus grandis · Pollen flow · Seed orchard · Paternity analysis $\cdot$ Microsatellite $\cdot$ Madagascar

Communicated by H.F. Linskens

G. Chaix $(-)$ V. Razafimaharo

Cirad-Forêt/Fofifa, B.P. 745, Antananarivo 101, Madagascar, e-mail: gilles.chaix@cirad.fr

Tel.: +261-2022-40623, Fax: +261-2022-40821

S. Gerber

INRA, Laboratoire de génétique et amélioration des arbres forestiers, BP 45, F-33611 Gazinet Cedex, France,

P. Vigneron · D. Verhaegen

Cirad-Forêt, Campus de Baillarguet TA 10C,

34398 Montpellier Cedex 5 France,

S. Hamon

IRD Montpellier, 911 Avenue Agropolis,

34032 Montpellier Cedex France

\section{Introduction}

In the last 5 years, the Malagasy market demand for Eucalyptus seed has reached 150 to $250 \mathrm{~kg}$ annually. Seed orchards have been developed through research in order to supply smallholders with locally improved varieties for a range of wood products (Chaix and Ramamonjisoa 2001).

Eucalyptus is subject to inbreeding depression. Effects have been recorded on seed yield, height, basal area and volume (Griffin and Cotteril 1988; Hardner and Potts 1995; Hardner and Tibbits 1998). In addition, for Eucalyptus grandis, leaf and stem deformities and a consistently reduced vigour after self-pollination have been reported (Hodgson 1976; Van Wyk 1981; Burgess and Williams 1996). Thus, in seed orchards, checking the origin of progenies is crucial.

Eucalypts are insect-pollinated species and have a mixed-mating reproductive system. The Eucalyptus genus overall outcrossing-rate is estimated to be up to $73 \%$ (Moran 1992). Typical of the Myrtaceae, E. grandis nectar preferentially attracts Apis mellifera (Davis 1997). In some countries, A. mellifera has been introduced into Eucalyptus seed-production areas to enhance seed production (Moncur et al. 1995). This insect is abundant in Madagascar but its efficiency in Eucalyptus pollination has not been verified. In this approach it is important to have efficient markers.

Highly polymorphic codominant markers such as microsatellites are increasingly used to study gene flow based on exclusion probabilities (Byrne et al. 1996; Dow and Ashley 1996; Streiff et al. 1998; Gerber et al. 2000). This kind of marker has been developed for Eucalyptus (Brondani et al. 1998) and could be used to test the breeding system in seed orchards. A multiplexing approach, of six discriminate microsatellites, was adapted to E. grandis (Chaix et al. 2002) and is available for studying seed-orchard efficiency.

When establishing seed orchards, forest-tree breeders attempt both to maximize breeding progress and preserve genetic diversity. Panmictic conditions are important 
because deviations from this theoretical model could lead to differences between obtained and predicted genetic gains from the seed orchard, and a significant geneticdiversity reduction (Plomion et al. 2001).

The aim of this study, in a Malagasy seed orchard, was to estimate the pollen-cloud composition and the genitor relative contributions, and the outcrossing rate of $E$. grandis. Tests were done in a seed orchard, using microsatellites to determine: (1) the level of random mating; (2) the level of self-fertilisation; (3) the percentage of trees contributing to the next generation; (4) the equilibrium participation of putative genitors; and (5) the pollen flow from outside the seed orchard.

\section{Materials and methods}

Study site

The E. grandis Hill ex Maiden seedling seed orchard (SSO), established in 1987, is located next to Moramanga, Toamasina province, in middle-east Madagascar (latitude: $18^{\circ} 07 \mathrm{~S}$, longitude: $48^{\circ} 13 \mathrm{~W}$, about 900 metres asl). The mean annual air temperature is $19^{\circ} \mathrm{C}$ and annual rainfall is $1,500 \mathrm{~mm}$.

The SSO encompasses 12 open-pollinated progenies of five provenances. A single tree-plot design, with 40 replicates of the 12 progenies (480 trees), was used. Initial spacing between trees was 3 $\times 3 \mathrm{~m}(1,111$ trees per hectare $)$ and the stand covers 0.6 ha $(84 \times$ $72 \mathrm{~m}$ ). The SSO was surrounded by two borderlines (192 trees from a mixing of 12 families). One selective thinning, based on the growth characters, was performed in 1992. This thinning totally eliminated the family number 5 , and the effective family sizes ranged from 10 to 86 trees. The current tree density is 580 trees per hectare with a total of 242 trees in the central plot and 107 trees in borderlines (Fig. 1). The mean height of SSO 11 year-old trees was 22 meters.

The data based on microsatellite markers, reported in this study, correspond to 349 mature trees of E. grandis and 724 progenies collected on 30 maternal trees highlighted in Fig. 1.

\section{DNA extraction and microsatellite analysis}

DNA extracts were prepared for the 349 trees of the seed orchard and 724 seedlings from seeds harvested in 1998 on 30 selected trees. The microsatellite loci were Embra06, Embra10, Embra11, Embra13, Embra15 and Embra19, and are located on different linkage groups.

Both simple PCR and multiplexed PCR were used. The multiplexed method was developed for this study and the protocol was described by Chaix et al. (2002). For simple PCR amplification, $9 \mathrm{ng}$ of genomic DNA were used in a final volume of $12 \mu \mathrm{l}$, $0.312 \mu \mathrm{M}$ of each primer, $0.1 \mathrm{mM}$ of each dNTP, $67 \mathrm{mM}$ of Tris$\mathrm{HCl}(\mathrm{pH} 8), 0.2 \mu \mathrm{g} \mu \mathrm{l}^{-1}$ of bovine serum albumin, $2.0 \mathrm{mM}$ of $\mathrm{MgCl}_{2}, 2 \mathrm{U}$ of $\mathrm{Taq}$ polymerase (Life Technologies ref. 180380026) and de-ionised water q.s. $12 \mu \mathrm{l}$. PCR involved a denaturing step of $94{ }^{\circ} \mathrm{C}$ for $4 \mathrm{~min}$ followed by 29 amplifications of the following cycle $\left(94{ }^{\circ} \mathrm{C}\right.$ for $1 \mathrm{~min}$ and 54, 56, 58 and $60{ }^{\circ} \mathrm{C}$ for $1 \mathrm{~min}$ respectively for the loci Embra13, Embra10-Embra11, Embra15Embra19 and Embra06, and $72{ }^{\circ} \mathrm{C}$ for $1 \mathrm{~min}$ ) and finally one cycle of $72{ }^{\circ} \mathrm{C}$ for $7 \mathrm{~min}$.

PCR products were mixed with a buffer $(95 \%$ formamide, $12.5 \%$ glycerol, $0.05 \%$ xylene cyanol, 0.05 bromophenol blue, $10 \mathrm{mM}$ of $\mathrm{NaOH}$ ) and denatured at $96{ }^{\circ} \mathrm{C}$ for $3 \mathrm{~min}$ before being resolved in $6 \%$ standard denaturing polyacrylamide gels, which were then silver-stained (Streiff et al. 1998). Electrophoretic patterns were analysed by double reading.

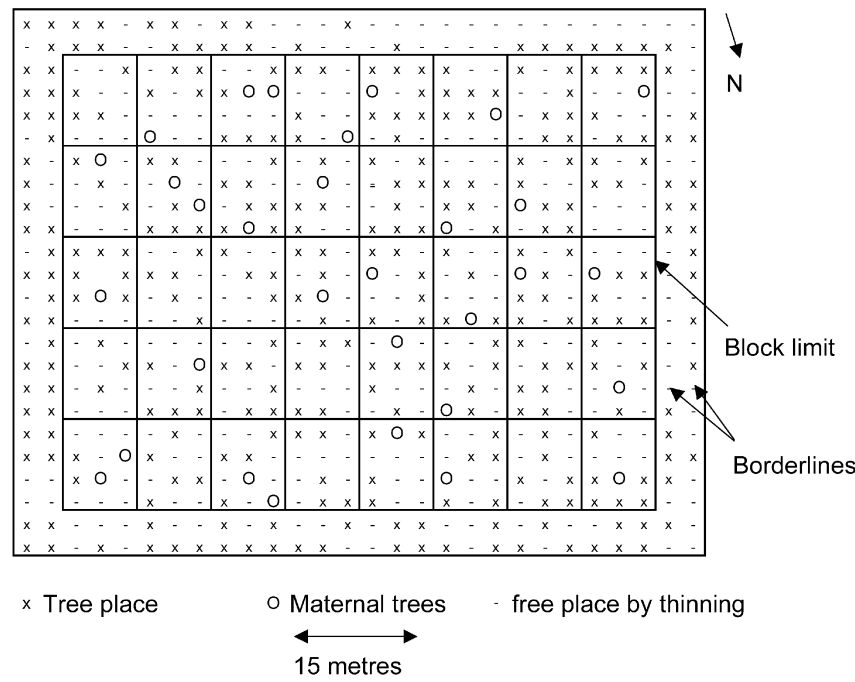

\begin{tabular}{clccr}
\hline Family & Provenance & Country & Effective size & \multicolumn{1}{c}{$\%$} \\
\hline 1 & Andranokobaka & Madagascar & 31 & 8.9 \\
2 & Andranokobaka & Madagascar & 30 & 8.6 \\
3 & Andranokobaka & Madagascar & 22 & 6.3 \\
4 & Atherton & Australia & 35 & 10.0 \\
5 & Atherton & Australia & 9 & 2.6 \\
6 & Tinaroo & Australia & 16 & 4.6 \\
7 & Tinaroo & Australia & 13 & 3.7 \\
8 & Tinaroo & Australia & 17 & 4.9 \\
9 & Ravenshoe & Australia & 26 & 7.4 \\
10 & Ravenshoe & Australia & 34 & 9.7 \\
11 & Paluma & Australia & 9 & 2.6 \\
Borderline trees & - & - & 107 & 30.7 \\
\hline & & & 349 & 100.0 \\
\hline
\end{tabular}

Fig. 1 Map of the E. grandis seedling seed orchard. Spatial distribution and family description

\section{Paternity assignment}

For each locus, allele frequencies were determined. Expected heterozygosity $\left(\mathrm{H}_{\mathrm{e}}\right)$ was estimated according to Nei's (1987) method. Statistical tests of Wright's fixation index (F) were performed by GENEPOP (Raymond and Rousset 1995). Microsatellite data were used in the paternity analysis, using FaMoz software (S. Gerber, unpublished), which assigns paternity to a particular pollen donor, based on the likelihood-ratio method. The paternity assignment methods by exclusion procedures were detailed in Streiff et al. (1999) and Gerber et al. (2000). The multilocus genotype of the mothers and 349 potential fathers was known for each offspring. The haplotype of the putative male parent of each offspring was inferred by subtracting the female contribution from its multilocus genotype. The maternal data were included to estimate selfing. The male haplotype was then compared to all possible haplotypes corresponding to the 349 trees of the seed orchard.

When allele frequencies in the population and genotypes from a set of offspring and a set of potential parents were available, the most-probable single father was identified by the calculation of LOD scores. A ratio compares the likelihood of an individual being the parent of a given offspring, divided by the likelihood of any other individual from the population being the parent (Meagher and Thompson 1986).

The population considered here was not isolated from other pollen sources, and the adult trees genotyped were only a subset of all the potential parents of the reproducing population. The total gene flow can therefore be subdivided into two different components: (GFO) gene flow from outside the stand and (GFI) gene flow from inside the stand (Gerber et al. 2000). Estimated GFO, using parentage analysis, is probably underestimated because foreign gametes and local gametes may be indistinguishable. Cryptic gene 
Table 1 Diversity parameters for six microsatellite loci, exclusion probability (EP) and identity probability (IP) for parental populations. $\left[\mathrm{A}_{\mathrm{o}}, \mathrm{A}_{\mathrm{e}}\right.$ : observed and efficient number of alleles, $\mathrm{H}_{\mathrm{o}}, \mathrm{H}_{\mathrm{e}}$ : observed and expected heterozygosity, $\left.\mathrm{F}=1-\left(\mathrm{H}_{\mathrm{o}} / \mathrm{H}_{\mathrm{e}}\right)\right]$

\begin{tabular}{llllllll}
\hline Locus & $\mathrm{A}_{\mathrm{o}}$ & $\mathrm{A}_{\mathrm{e}}$ & $\mathrm{H}_{\mathrm{o}}$ & $\mathrm{H}_{\mathrm{e}}$ & $\mathrm{F}$ & $\mathrm{EP}$ & $\mathrm{IP}$ \\
\hline Embra06 & 21 & 6.4 & 0.8420 & 0.8446 & $0.0031^{\mathrm{ns}}$ & 0.698 & 0.039586 \\
Embra10 & 14 & 7.7 & 0.8391 & 0.8705 & $0.0361^{\mathrm{ns}}$ & 0.738 & 0.029648 \\
Embra11 & 17 & 3.4 & 0.6185 & 0.7062 & $0.1242^{*}$ & 0.519 & 0.106655 \\
Embra13 & 19 & 2.6 & 0.7049 & 0.6163 & $-0.1494^{\mathrm{ns}}$ & 0.424 & 0.167533 \\
Embra15 & 20 & 8.3 & 0.4737 & 0.8813 & $0.4624^{* *}$ & 0.761 & 0.024531 \\
Embra19 & 10 & 2.9 & 0.4770 & 0.6578 & $0.2749^{* *}$ & 0.435 & 0.152592 \\
All locus & 16.8 & 5.2 & 0.6592 & 0.7623 & $0.1352^{* *}$ & 0.997 & 0.000132 \\
\hline
\end{tabular}

Level of significance: ${ }^{\mathrm{ns}}=p>0.05, *=p<0.05,{ }^{*} *=p<0.01$ flow corresponds to GFO events that have been falsely attributed to GFI events (Devlin and Ellstrand 1990).

Using the genotypes of the 349 trees at the six microsatellite loci, we generated 10,000 random offspring. In set 1 , each offspring had a father among the 349 trees, randomly chosen, with selfing possible (GFI). In set 2, each offspring was constructed by randomly picking a mother and a gamete in the mother, and by selecting the second allele at each locus at random, according to their frequency. Fathers of these offspring were assumed not to be among the 349 genotyped trees (GFO). Genotyping error $(0.1 \%)$ could be included in the simulation. The potential fathers giving the highest LOD scores were recorded and the distributions of these LOD scores were plotted. We compared the distributions of LOD scores of the most-likely father of the offspring from set 1 with those of the offspring from set 2 . In order to minimise type-I and type-II errors, thresholds of LOD scores were chosen at the intersection of the two distributions. The test was applied to simulated data, to check the proportion of correct decisions made (Gerber et al. 2000).

Pollination pattern

Pollination efficiency depends on insect activity and individual floral contribution, tree distances and the dominant wind direction. Male-mating success, as a function of distance, was analysed by subdividing the neighbourhood of a maternal tree into increasing 9 metre distance classes. This distance was chosen in accordance with the size of the seed orchard, and because spacing between trees was 3 metres. The offspring fertilised by such or such a father are entered in the class corresponding to the distance between the two parents. The offspring fertilised by paternal trees were included in each distance according to the maternal tree. The number of pollinating male parents was compared with the potential number of trees. Comparisons were made using a one-tailed MannWhitney-Wilcoxon test of the null hypothesis that no distancerestriction applies to pollination.

\section{Results}

Six microsatellites were used to screen the diversity of 973 E. grandis genotypes. They correspond to the seed orchard 349 trees, the parental population and 724 seedlings harvested on 30 parental trees.

\section{Genetic diversity of the parental populations}

Diversity parameters for six microsatellite loci, exclusion probability (EP) and identity probability (IP) for parental populations are reported in Table 1. Microsatellite markers were highly polymorphic for the parental population with a total of 101 different alleles. The number of alleles per locus $\left(\mathrm{A}_{\mathrm{o}}\right)$ ranged from 10 (Embra19) to 21
Table 2 Diversity parameters for six microsatellite loci in offspring populations $\left[\mathrm{A}_{0}, \mathrm{~A}_{\mathrm{e}}\right.$ : observed and efficient number of alleles, $\mathrm{H}_{\mathrm{o}}$, $\mathrm{H}_{\mathrm{e}}$ : observed and expected heterozygosity, $\left.\mathrm{F}=1-\left(\mathrm{H}_{\mathrm{o}} / \mathrm{H}_{\mathrm{e}}\right)\right]$

\begin{tabular}{llllll}
\hline Locus & $\mathrm{A}_{\mathrm{o}}$ & $\mathrm{A}_{\mathrm{e}}$ & $\mathrm{H}_{\mathrm{o}}$ & $\mathrm{H}_{\mathrm{e}}$ & $\mathrm{F}$ \\
\hline Embra06 & 20 & 5.2 & 0.7375 & 0.8076 & $0.0891^{* *}$ \\
Embra10 & 17 & 7.4 & 0.8584 & 0.8660 & $0.0081^{\mathrm{ns}}$ \\
Embra11 & 17 & 3.3 & 0.6481 & 0.6965 & $0.0695^{\mathrm{ns}}$ \\
Embra13 & 17 & 2.7 & 0.7431 & 0.6260 & $-0.1871^{\mathrm{ns}}$ \\
Embra15 & 15 & 5.0 & 0.5129 & 0.8009 & $0.3596^{* *}$ \\
Embra19 & 14 & 2.9 & 0.5793 & 0.6620 & $0.1249^{* *}$ \\
All locus & 16.5 & 4.1 & 0.6799 & 0.7435 & $0.0855^{* *}$ \\
\hline
\end{tabular}

Level of significance: ${ }^{\mathrm{ns}}=p>0.05, * *=p<0.01$

(Embra06) with a mean of 16.8. The effective number of alleles $\left(\mathrm{A}_{\mathrm{e}}\right)$ reflects the difference in polymorphism between microsatellite loci. Values of parental $A_{e}$ varied from 2.9 to 8.3 with an average of 5.2. The observed heterozygosity $\left(\mathrm{H}_{\mathrm{o}}\right)$ ranged from 0.47 (Embra15 and Embra19) to 0.84 (Embra06 and Embra10). Deviations from Hardy-Weinberg expectations measured as the heterozygote deficiency $(\mathrm{F})$ showed a statistically highly significant heterozygosity deficit (0.1352). High exclusion probability $(\mathrm{EP}=0.9970)$ and low identity probability (IP $=0.000132)$ confirm that six microsatellite markers are enough, under our conditions, for paternity assignment. A LOD score threshold of 4.7 was considered sufficient to choose a potential parent as the true father.

Genetic diversity of the offspring populations

Diversity parameters for six microsatellite loci in offspring populations are reported in Table 2. The allele number per locus ranged from 14 (Embra15 and Embra19) to 20 (Embra06) with a mean of 16.5. Values of offspring $\mathrm{A}_{\mathrm{e}}$ varied from 2.9 to 7.4 with an average of 4.1. As for the parental populations, the $\mathrm{F}$ value for the progeny population showed a statistically highly significant heterozygosity deficit $(0.0855)$ and the locus Embra15 has the maximum and statistically highest significant values.

\section{Paternity assignment}

Results of paternity assignment for 30 progenies are recorded in Table 3 . The 724 plants correspond to seeds harvested on 30 maternal trees for which sample sizes 
Table 3 Result of paternity assignment for 30 progenies $(\mathrm{N}$ : number of analysed seedlings, $\mathrm{N}_{1}$ : number of seedlings matching a male parent in the seed orchard, $\mathrm{N}_{2}$ : number of seedlings resulting from selfing, $\mathrm{t}_{\mathrm{m}}$ : outcrossing rate, $\mathrm{N}_{3}$ : observed male number)

\begin{tabular}{|c|c|c|c|c|c|c|c|}
\hline Maternal tree & Family & $\mathrm{N}$ & $\mathrm{N}_{1}$ & $\mathrm{~N}_{1} / \mathrm{N}(\%)$ & $\mathrm{N}_{2}$ & $\mathrm{t}_{\mathrm{m}}(\%)$ & $\mathrm{N}_{3}$ \\
\hline 1 & 1 & 20 & 13 & 65.0 & 2 & 90.0 & 12 \\
\hline 2 & 10 & 23 & 7 & 30.4 & 1 & 95.7 & 7 \\
\hline 3 & 1 & 20 & 13 & 65.0 & 0 & 100.0 & 10 \\
\hline 4 & 3 & 11 & 6 & 54.5 & 0 & 100.0 & 6 \\
\hline 5 & 8 & 18 & 13 & 72.2 & 0 & 100.0 & 13 \\
\hline 6 & 1 & 19 & 12 & 63.2 & 0 & 100.0 & 11 \\
\hline 7 & 2 & 20 & 13 & 65.0 & 0 & 100.0 & 12 \\
\hline 8 & 9 & 19 & 14 & 73.7 & 1 & 94.7 & 13 \\
\hline 9 & 4 & 20 & 11 & 55.0 & 0 & 100.0 & 10 \\
\hline 10 & 8 & 50 & 26 & 52.0 & 0 & 100.0 & 24 \\
\hline 11 & 2 & 20 & 9 & 45.0 & 0 & 100.0 & 8 \\
\hline 12 & 4 & 20 & 9 & 45.0 & 0 & 100.0 & 7 \\
\hline 13 & 2 & 48 & 23 & 47.9 & 1 & 97.9 & 21 \\
\hline 14 & 4 & 22 & 16 & 72.7 & 2 & 90.9 & 8 \\
\hline 15 & 8 & 18 & 15 & 83.3 & 0 & 100.0 & 12 \\
\hline 16 & 1 & 18 & 8 & 44.4 & 0 & 100.0 & 8 \\
\hline 17 & 7 & 60 & 39 & 65.0 & 1 & 98.3 & 31 \\
\hline 18 & 9 & 19 & 9 & 47.4 & 0 & 100.0 & 8 \\
\hline 19 & 4 & 20 & 13 & 65.0 & 0 & 100.0 & 10 \\
\hline 20 & 8 & 19 & 14 & 73.7 & 0 & 100.0 & 14 \\
\hline 21 & 3 & 20 & 14 & 70.0 & 0 & 100.0 & 13 \\
\hline 22 & 3 & 19 & 10 & 52.6 & 0 & 100.0 & 10 \\
\hline 23 & 4 & 22 & 15 & 68.2 & 0 & 100.0 & 13 \\
\hline 24 & 1 & 60 & 41 & 68.3 & 1 & 98.3 & 21 \\
\hline 25 & 1 & 19 & 12 & 63.2 & 0 & 100.0 & 12 \\
\hline 26 & 2 & 20 & 13 & 65.0 & 1 & 95.0 & 10 \\
\hline 27 & 3 & 19 & 14 & 73.7 & 5 & 73.7 & 8 \\
\hline 28 & 2 & 19 & 14 & 73.7 & 2 & 89.5 & 12 \\
\hline 29 & 4 & 20 & 12 & 60.0 & 1 & 95.0 & 12 \\
\hline 30 & 3 & 22 & 12 & 54.5 & 6 & 72.7 & 7 \\
\hline Total & & 724 & 440 & - & 24 & - & 199 \\
\hline Average & & - & - & 60.8 & - & 96.7 & \\
\hline
\end{tabular}

varied from 11 to 60 plants. Depending on the mother, the frequency of allopollination varied from 72.7 to 100 and averaged $96.7 \%$. The outside pollen rate was deduced from the percentage of progenies whose paternity was not determined inside the seed orchard. On average, gene flow by pollen inside the orchard was $60.8 \%$, ranging from 30.4 to $73.7 \%$ depending on the mother. It was $39.2 \%$ outside the orchard - ranging from 26.3 to $69.6 \%$.

If we consider the 440 seedlings fathered by male parents from the seed orchard, 199 trees $(56 \%)$ participated as pollen donors. Among identified pollen donors, $103(51.7 \%)$ fathered two or more progenies. The maximum was 12 . For a given male parent, the mean contribution reached 2.1 offspring. Each of them had 1 to 7 partners on 30 maternal trees and half of the paternal trees $(49.7 \%)$ were involved in only one mating event (Fig. 2).

In Table 4, we reported the family and provenance ratio for parental and identified populations. Five provenances (11 families) composed the seed orchard. Unequal contributions were observed for pollen donors for families 3 (Andranokobaka), 9 and 10 (Ravenshoe). Families 9 and 10 , with a ratio near 0.5 , were under-represented in the observed pollen cloud; conversely, the family 3 , with a ratio of 2.02, was over-represented. In the observed pollen cloud, the borderline trees contributed $30 \%$ of the potential male population.

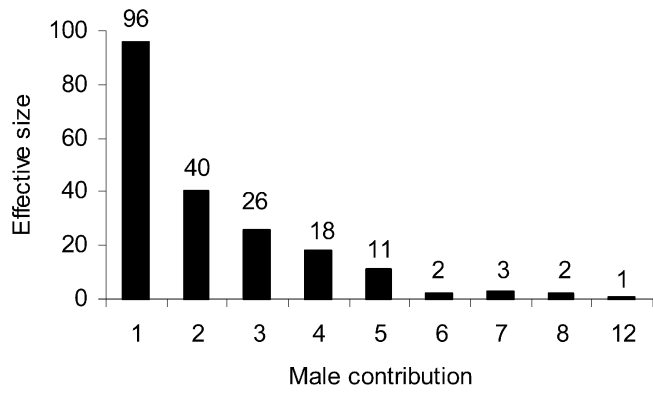

Fig. 2 Distribution of male contributions (total number of fathers = 199). Each bar corresponds to the number of times a pollen donor pollinated a mother tree

\section{Pollination patterns}

The geographic distributions of pollen donors are presented for eight maternal trees (Fig. 3). Within the seed orchard, the pollination pattern did not seem to have a particular direction. The distribution behaviour of pollen donors for each maternal tree seemed to be independent of their position in the seed orchard. Nevertheless, distances between the maternal tree and the pollen donor were similar to the size of the seed orchard.

The distributions of potential vs identified male parents, as a function of distance from the maternal tree, are illustrated in Fig. 4. Even if there were statistically 
Fig. 3 Distribution of pollen parents within the seed orchard ( 84 by 72 metres) for eight maternal tree progenies $(1,10$, $13,15,17,23,24,28)$. Open circles $(\bigcirc)$ indicate pollen parents. Lines indicate pollen flow to the maternal tree. Line thickness is proportional to the number of successful pollen grains of the paternal tree. Arrows with \%: percentage of offspring from a parent identified outside the seed orchard
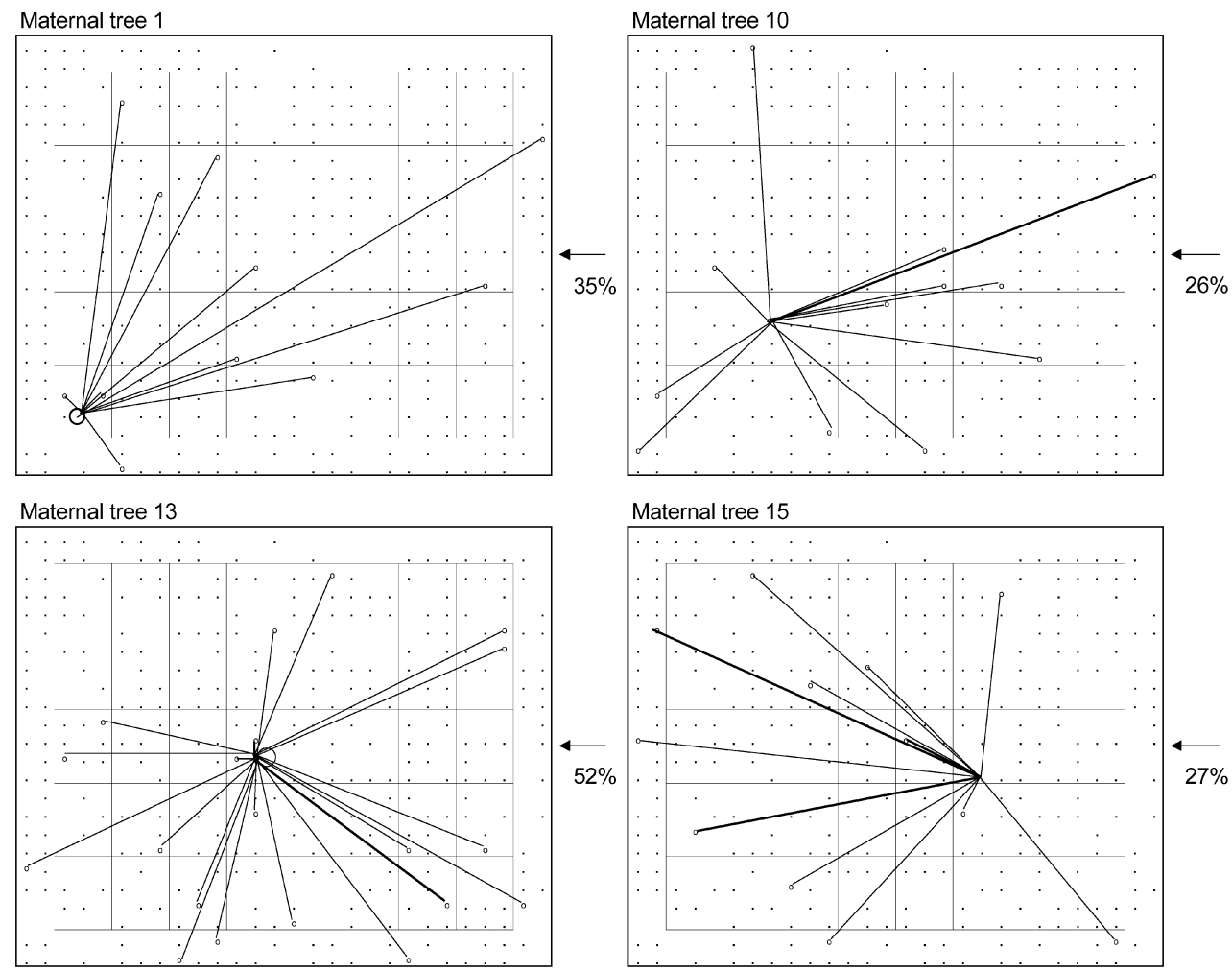

Maternal tree 17

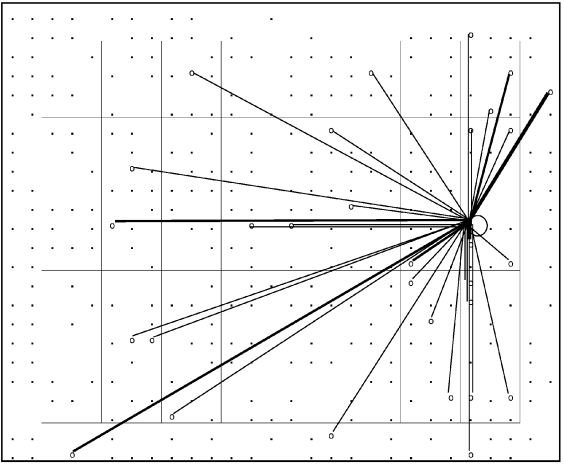

Maternal tree 23

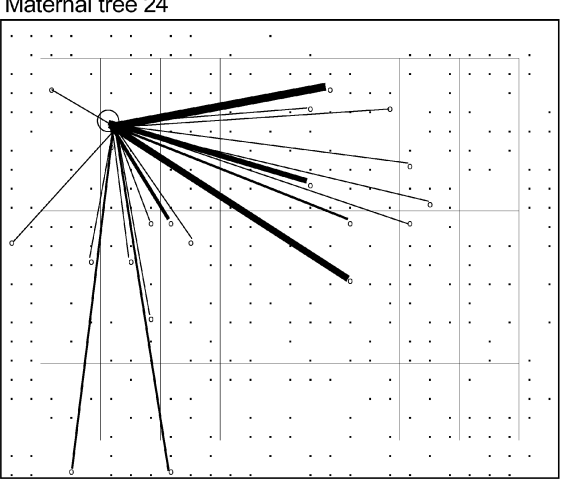

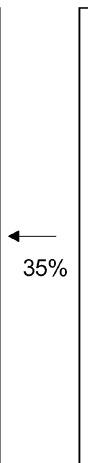
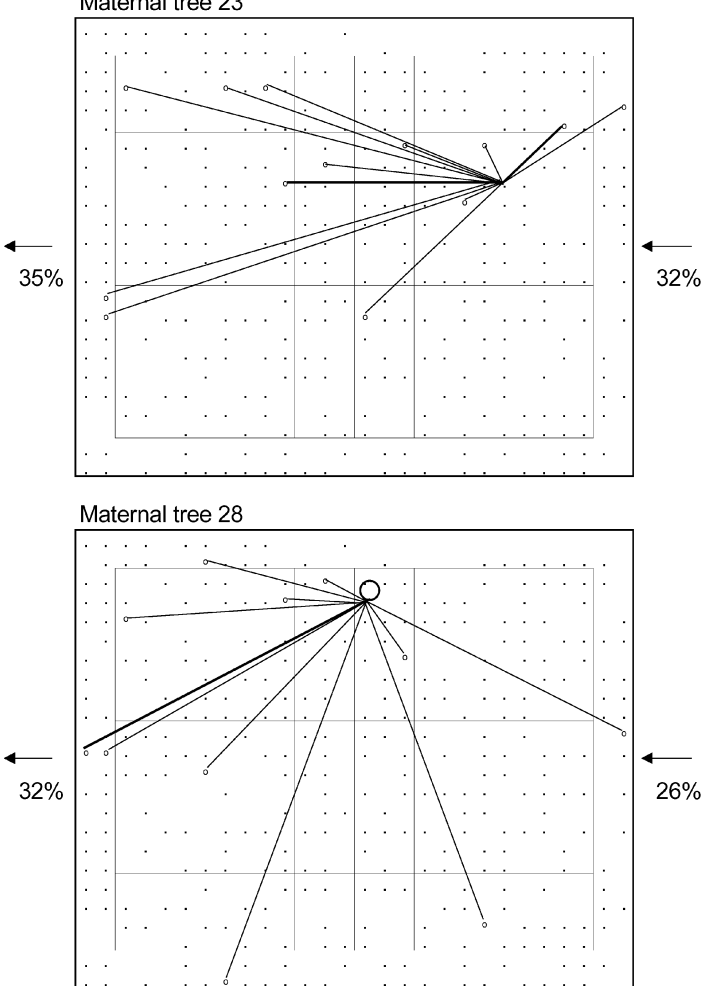

significant deviations between expected and observed distributions for two mothers (17 and 24), all the maternal data showed that there was not a statistically significant excess of neighbouring pollinating parents in comparison with the potential pollen donors. Based on the relative position of paternal trees and maternal trees within the seed orchard, the mean distance of pollination was 32 metres with a maximum value of 85 metres. The pollination mean distances for each maternal trees depended on their place in the seed orchard because the 
Table 4 Family and provenance ratio for parental and male-identified populations. Ratio was calculated as the frequency of the family (or provenance) for the identified male population divided by the frequency of the family (or provenance) for the parental population

\begin{tabular}{llcl}
\hline Provenance & Provenance level & Family identification & Family level \\
\hline Andranokobaka & 1.41 & 1 & 1.16 \\
& & 2 & 1.23 \\
Atherton & 0.95 & 3 & 2.02 \\
& & 4 & 1.03 \\
Tinaroo & 1.18 & 5 & 0.65 \\
& & 6 & 1.78 \\
Ravenshoe & 0.47 & 7 & 0.65 \\
& & 8 & 1.02 \\
Paluma & 1.11 & 10 & 0.53 \\
Borderline trees & 0.90 & 11 & 0.42 \\
\hline
\end{tabular}
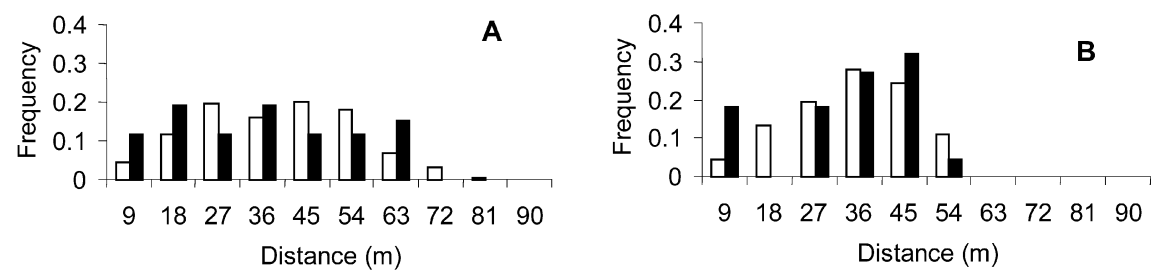

Fig. 4 Potential (white bars) and pollinating (black bar) male-parent distributions as a function of the distance to the four maternal trees (A: 10, B: 13, C: $17, \mathbf{D}: 24)$ and all 30 maternal trees $(\mathbf{E})$. One-tailed Mann-Whitney-Wilcoxon tests were applied to the shift to the left observed in the potential distribution (restriction caused by the distance), in the distance classes. Mother trees 17 and 24 both show a statistically significant deviation between potential and effective distributions at the $5 \%$ level
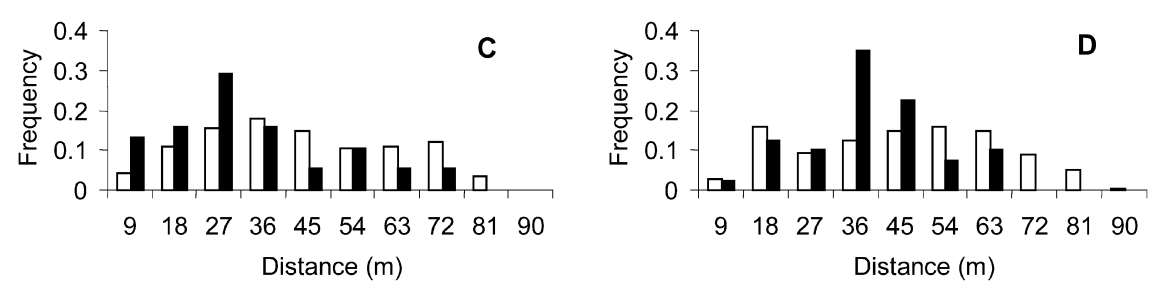

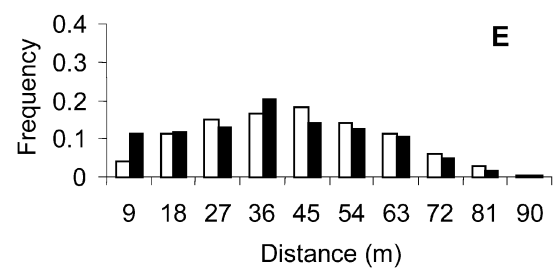

relative mean distance for a tree near the borderline was greater than for a tree in the central zone of the seed orchard.

\section{Discussion}

Microsatellite markers were used for paternity analysis of 349 Eucalyptus parental trees located in a Malagasy seed orchard. Microsatellite markers appeared to be powerful tools for tracing pollen flow in this context. Results showed that the overall outcrossing rate was high (96.7\%) with little differential contributions according to family and provenances. In the seed orchard, half the paternal trees participated in pollination for 30 progenies (440 individuals) and no particular pollination direction was observed. Nevertheless, the pollen flow from outside the stand reached nearly $40 \%$.
Reproductive behaviour inside the seed orchard

The use of six Eucalyptus microsatellites gave highexclusion and high-identity probabilities. These observations confirmed that a few microsatellite markers were enough for paternity assignment. As shown for some other species, the large number of low-frequency alleles and their distributions, typical of microsatellite loci, positively influence the exclusion probabilities (Dow and Ashley 1998; Streiff et al. 1999; Kameyama et al. 2000; Konuma et al. 2000).

The overall outcrossing rate was high $(96.7 \%)$ with no neighbouring effect. On the female side, it could be argued that a sample of 30 progenies, $10 \%$ of the 349 potential trees, is unrepresentative of the totality. But, on the male side, more than $50 \%$ of potential male parents contributed to the 362 identified matings. If we examine the results at the level of families or origins, the parental 
population contribution was slightly unequal. Paternal trees from families 9 and 10, the Ravenshoe provenance, were under-represented in the pollen cloud. Unpublished data seems to indicate phenological problems, whose families flowered later than other provenances.

Few studies concern data on outcrossing rate in Eucalyptus seed orchards. In addition, plantations and establishment conditions (density, height, genotype and random unrelated neighbouring) could modify outcrossing rate (Moran et al. 1989).

In seed orchards, Sato and Mori (1996) reported slightly lower values for $E$. grandis $\left(\mathrm{t}_{\mathrm{m}}=87.2 \%\right)$ but Moran et al. (1989) obtained higher values for Eucalyptus regnans $\left(\mathrm{t}_{\mathrm{m}}=91 \%\right)$. Concerning Eucalyptus globulus, the outcrossing rate varied according to stand density. The value was near $100 \%$ in the closed forest but lowerdensity (one tree per hectare) individual values decreased from $81 \%$ to $48 \%$ (Hardner et al. 1998).

In natural populations, the outcrossing rate seemed lower than in seed orchards. Few studies have reported this rate for $E$. grandis in exotic conditions but data were reported for other species. Moran et al (1989) found 74\% in an E. regnans natural population. For Eucalyptus citriodora, Yeh et al. (1983) reported an outcrossing rate of $85 \%$ estimated with isozymes. For Eucalyptus urophylla, Gaiotto et al. (1997) estimated around 90\% with RAPD and AFLP markers.

The within-tree harvest location or the relative size of the trees could modify the estimation. Moran and Brown (1980) showed that, usually, the viability of seeds resulting from self-pollination was lower and the estimated outcrossing rate increases with seed maturity. Consequently, it is possible that the true degree of outcrossing in the seed orchard may be lower because a part of the inbred-seeds did not germinate or have a lower viability. This could be important from a basic point of view but could be easily managed with microsatellites. Seeds are harvested preferentially from the bottom of the canopy. It will be interesting to control the outcrossingrate variability due to the different capsule positions in the crown. Different levels constitute the canopy and pollen flow, and may differ from one level to another. In the natural forest, Patterson et al. (2001) reported a lower outcrossing rate for suppressed trees than for dominant trees. Crosses could preferentially occur into the bottom or top of the canopy. It would be interesting to verify whether the most-accessible seed is the most inbred and if seeds result from crosses into this part of the canopy.

Reproductive behaviour outside the seed orchard

The pollen flow from outside the stand reached nearly $40 \%$. Clearly, the seed orchard was not spatially isolated from other populations and a high proportion of alien pollen flow was found. The percentage of individualcontamination by alien pollen varied from 26.3 to $69.6 \%$.

The small-orchard area is one of the main reasons for these observations. Contamination rate is probably linked to the seed-orchard area because the seed-orchard length was smaller than the potential distance of pollination. The nearest pollen sources were the Eucalyptus robusta test (interfertile with E. grandis) and the E. grandis seedorchard was located 100 and 400 metres away, respectively. Other sources, essentially of E. robusta, were situated at one kilometre. Grosser et al. (2001) reported a contamination rate of 5\% in an Eucalyptus nitens Australian seed orchard, but the experimental conditions were not described. The presence of bees in the area also suggested that pollen could be carried several kilometres and be exchanged in the hive (B. Vaissiere, personal communication). Microsatellite markers helped to demonstrate that long-distance pollen-flow within populations is relatively common for wind-pollinated species (Dow and Ashley 1996; Streiff et al. 1999) and insectpollinated species (Chase et al. 1996; Horskins and Turner 1999; Konuma et al. 2000).

These results are not exceptional and such a phenomenon is frequent. The contamination rate for a pine-seed orchard ranged from 14 to $74 \%$ (Pakkanen et al. 2000). A common trend, among oak studies, is a high percentage (50-70\%) of offspring with male parents outside the study sites (Dow and Ashley 1998; Streiff et al. 1999). Konuma et al. (2000) studied a low-density stand of insectpollinated (by stingless bees or Apis spp.) Neobalanocarpus heimii. They found an alien pollen rate of $29 \%$, ranging from 21 to $69 \%$. The estimated average mating distance exceeded 500 metres. Using a similar approach, Kameyama et al. (2000) estimated 20 to $30 \%$ alien pollen for Rhododendron metternichii.

In conclusion, even if we estimated that the high contamination rate was related to the small size of this seed orchard, and we suspected preferential mating within early or late-flowering trees and within dominant or suppressed trees, "panmixia-like pollination" can be assumed. In addition, the study showed that it is possible to identify the paternal origin of young plantlets before planting. This enables the breeder to rapidly create a "true" panmictic population, with an equilibrium between the different genotypes and populations by excluding plants from self-fertilisation, related individual crosses or with a paternal origin outside the seed orchard.

Acknowledgements This paper represents a portion of the doctoral research of G. Chaix supported by the Scientific Directorate of Cirad (ATP Vergers à graines) and by Cirad-forêt. We wish to thank F. Rasolo, Y. Rabenantoandro, H. Randrianjafy (Fofifa), G. Rabetsoa (Fanalamanga) and A. Charrier (Ensam) for agreeing to conduct this work in Madagascar, J.C. Maillard, I. Chantal, M. Poitel and S. Razafiarivelo for their help in the laboratory, and J. Rakotonjanahary, N. Ratovoson and J. Rakotondrasoa for their field work.

\section{References}

Brondani RPV, Brondani C, Tarchini R, Grattapaglia D (1998) Development characterization and mapping of microsatellite markers in Eucalyptus grandis and Eucalyptus urophylla. Theor Appl Genet 97:816-827 
Burgess IP, Williams ER (1996) The effect of outcrossing rate on the growth of selected families of Eucalyptus grandis. Silvae Genet 45:2-3

Byrne M, Marquez Garcia MI, Uren T, Smith DS, Moran GF (1996) Conservation and genetic diversity of microsatellite loci in the genus Eucalyptus. Aust J Bot 44:331-341

Chaix G, Ramamonjisoa L (2001) Production de semences pour les reboisements malgaches. Bois et Forêts des Tropiques 269:4963

Chaix G, Chantal I, Poitel M, Razafiarivelo S, Verhaegen S, Maillard JC (2002) Microsatellite primer amplification by multiplexing: a first application to Eucalyptus grandis. Plant Mol Biol Rep 20:67a-67e

Chase MR, Moller C, Kessel R, Bawa K (1996) Distant gene flow in a tropical tree. Nature 383:398-399

Davis AR (1997) Influence of floral visitation on nectar-sugar composition and nectary surface changes in Eucalyptus. Apidologie 28:27-42

Devlin B, Ellstrand NC (1990) The development and application of a refined method for estimating gene flow from angiosperm paternity analysis. Evolution 44:248-259

Dow BD, Ashley MV (1996) Microsatellite analysis of seed dispersal and parentage of saplings in bur oak, Quercus macrocarpa. Mol Ecol 5:615-627

Dow BD, Ashley MV (1998) High levels of gene flow in bur oak revealed by paternity analysis using microsatellites. Heredity 89:62-70

Gaiotto FA, Bramucci M, Grattapaglia D (1997) Estimation of outcrossing rate in a breeding population of Eucalyptus urophylla with dominant RAPD and AFLP markers. Theor Appl Genet 95:5-6

Gerber S, Mariette D, Streiff R, Bodénès C, Kremer A (2000) Comparison of microsatellites and amplified fragment length polymorphism markers for parentage analysis. Mol Ecol 9:1037-1048

Griffin AR, Cotteril PP (1988) Genetic variation in growth of outcrossed, selfed and open-pollinated progenies of Eucalyptus regnans and some implications for breeding strategy. Silvae Genet 37:124-131

Grosser C, Vaillancourt R, Potts B, O’Sullivan H (2001) Paternity analysis in a Eucalyptus nitens clonal seed orchard. In: Proceedings Developing the Eucalypts of the Future. IUFRO Int Symp 10-15 Sept 2001, Valdivia, Chile

Hardner CM, Potts BM (1995) Inbreeding depression and changes in variation after selfing in Eucalyptus globulus ssp. globulus. Silvae Genet 44:46-54

Hardner C, Tibbits W (1998) Inbreeding depression for growth, wood and fecundity traits in Eucalyptus nitens. For Genet 5:1120

Hardner CM, Potts BM, Gore PL (1998) The relationship between cross success and spatial proximity of Eucalyptus globulus ssp. globulus parents. Evolution 52:614-618

Hodgson LM (1976) Some aspects of flowering and reproductive behavior in Eucalyptus grandis (Hill) Maiden at JDM Keet Forest Research Station. 2. The fruit, seed, seedlings, self fertility, selfing and inbreeding effects. South Afric For J 97:32-43
Horskins K, Turner VB (1999) Resource use and foraging patterns of honeybees, Apis mellifera, and native insects on lowers of Eucalyptus costata. Aust J Ecol 24:221-227

Kameyama Y, Isagi Y, Naito K, Nakagoshi N (2000) Microsatellite analysis of pollen flow in Rhododendron metternichii var. hondunese. Ecol Res 15:263-269

Konuma A, Tsumura Y, Lee CT, Lee SL, Okuda T (2000) Estimation of gene flow in the tropical-rainforest tree Neobalanocarpus heimii (Dipterocarpaceae), inferred from paternity analysis. Mol Ecol 9:1843-1852

Meagher TR, Thompson E (1986) The relationship between single parent and parent-pair genetic likelihoods in genealogy reconstruction. Theor Pop Biol 29:87-106

Moncur MW, Mitchell A, Fripp Y, Kleinschmidt GJ (1995) The role of honeybees (Apis mellifera) in eucalypt and acacia seedproduction areas. Com For Rev 64:350-354

Moran GF (1992) Patterns of genetic diversity in Australian tree species. New For 6:49-66

Moran GF, Brown AHD (1980) Temporal heterogeneity of outcrossing rates in alpine ash (Eucalyptus delegatensis R.T. Bak.). Theor Appl Genet 57:101-105

Moran GF, Bell JC, Griffin AR (1989) Reduction in levels of inbreeding in a seed orchard of Eucalyptus regnans F. Muell. compared with natural populations. Silvae Genet 38:32-36

Nei M (1987) Molecular evolutionary genetics. Columbia University Press, New York

Pakkanen A, Nikkanen T, Pulkkinen P (2000) Annual variation in pollen contamination and outcrossing in a Picea abies seed orchard. Scand J For Res 15:399-404

Patterson B, Potts B, Vaillancourt R (2001) Variation in outcrossing rates within the canopy of Eucalyptus globulus. In: Proceedings Developing the Eucalypts of the Future. IUFRO Int Symp 10-15 Sep 2001, Valdivia, Chile

Plomion C, LeProvost G, Pot D, Vendramin G, Gerber S, Decroocp S, Brach J, Raffin A, Pastuszka P (2001) Pollen contamination in a maritime pine polycross seed orchard and certification of improved seeds using chloroplast microsatellites. Can J For Res 31:1816-1825

Raymond M, Rousset F (1995) GENEPOP (version 1.2): population genetics software for exact tests and ecumenicism. J Hered $83: 239$

Sato AS, Mori ES (1996) Detection of inbreeding in seeds of Eucalyptus grandis Hill ex Maiden. Rev Inst Flor 8:131-134

Streiff R, Labbe T, Bacilieri R, Steinkeller H, Glössl, Kremer A (1998) Within-population genetic structure in Quercus robur L. and Quercus petraea (Matt.) Liebl. assessed with isozymes and microsatellites. Mol Ecol 7:317-328

Streiff R, Ducousso A, Lexer C, Steinkellner H, Gloessl J, Kremer A (1999) Pollen dispersal inferred from paternity analysis in a mixed oak stand of Quercus robur and Q. petraea. Mol Ecol 8:831-841

Van Wyk G (1981) Inbreeding effects in Eucalyptus grandis in relation to the degree of relatedness. South Afr For J 116:60-63

Yeh F, Brune A, Cheliak WM, Chipman DC (1983) Mating system of Eucalyptus citriodora in a seed-production area. Can J For Res 13:1051-1055 